\title{
A COVID-19 GERANDO IMPLICAÇÕES NA SOCIEDADE BRASILEIRA NO DIREITO PENAL E PROCESSUAL NO BRASIL
}

\author{
COVID-I9 GENERATING IMPLICATIONS IN BRAZILIAN SOCIETY IN CRIMINAL AND \\ PROCEDURAL LAW IN BRAZIL
}

\author{
Fernando Alves Costa ${ }^{1}$
}

RESUMO: Este artigo abordará de forma sintética a pandemia do novo coronavírus (COVID-ig) em confronto com as normas determinadas a sociedade pelo estado com base em fundamentos legais, com o objetivo de prevenir que o vírus se propague entre a população e evidenciar às leis, normas do direito, portarias e decretos adotados na atual crise socioeconômica. Visando a percepção de como na prática as normas no Brasil podem acarretar a prevenção do aumento da circulação do vírus, delimitando as sanções de delitos que deverão ser impostas ao cidadão que descumprir as normas estabelecidas de forma obrigatória.

Palavras-chave: Processo Penal Brasileiro. Covid-ıg. Coronavírus. A Lei Penal.

ABSTRACT: This article intends to approach in a synthetic way the pandemic of the new coronavirus (COVID-19) in confrontation with the norms determined to the society by the state based on legal bases, with the objective of preventing the virus from spreading among the population and evidencing the laws, rules of law, ordinances and decrees adopted in the current socioeconomic crisis. Aiming at the perception of how in practice the rules in Brazil can prevent the increase in the circulation of the virus, delimiting the sanctions of crimes that should be imposed on the citizen who does not comply with the rules established in a mandatory manner.

Keywords: Brazilian Criminal Procedure. Covid-ı. Coronavirus. The Criminal Law.

\section{INTRODUÇÃO}

O atual estado pandêmico do novocoronavírus, conhecido como COVID-iq, impõe uma grande mudança no que hoje conhecemos como controle epidemiológico, a relação sócioeconômica, a relação política, cultural, histórica e como tratar juridicamente cada caso que seja submetido as normas brasileiras.

\footnotetext{
1 Farmacêutico Bioquímico com especialidade em Análises Clínicas, Farmacologia Clínica, Hematologia Clínica, Farmacologia e Mestradoem Química. E-mail: fernandocostaalves@yahoo.com.br.
} 
É fato que o vírus teve como marco zero a China, que devido aos seus costumes otimizou que este agente etiológico infectasse o organismo humano e assim dando início a propagação do vírus extremamente letal devido a sua facilidade de contágio, logo como estratégia foi adotado o isolamento social, tendo como objetivo evitar a propagação e diminuir o número de infectados e mesmo assim ocorrendo a superlotação das unidades de saúde em todo o Brasil.

O nosso país registou o caso zero do novo coronavírus em 22 de março de 2020, sendo liberado um montante de aproximadamente I,6 bilhões de reais para que fosse combatido, visto que, o impacto global já era estabelecido e preocupante.

Estudiosos acreditam que somente a ampla coordenação dos dirigentes mundiais e instituições financeiras, aliadas à assistência a sociedade não seja limitada somente a propagação do vírus, sendo o Estado tendo como meta evitar a disseminação do vírus, estabelecer diretrizes e o cidadão buscar atender a estas normas e no caso não cumprimento das suas obrigações sofrerá sanção para punição.

Este trabalho objetiva tornar explícitas as mudanças na legislação brasileira determinada pelo estado de modo a que possa ocorrer o controle da propagação do vírus, evitando que as unidades de saúde fiquem superlotadas e assim implicando na falta de atendimento a todas as enfermidades que necessite de tratamento.

A saúde pública deve ser tratada de forma especial, devido ao fato que podem atingir a um grande número de indivíduos, no caso da Covid-19, somos informados diariamente sobre atitudes que vão de encontro as recomendações realizadas pelos órgãos especializados e as autoridades no que tange principalmente ao isolamento social. Devido a estes procedimentos medidas criminais foram implementadas e colocadas como essenciais para o enfrentamento a esse vírus com potencial de letalidade.

O projeto de Lei n. 23/2020 tem como finalidade adoção de medidas para combate da emergência quanto a saúde pública com relevância internacional dos eventos envolvendo o novo coronavírus, sendo encaminhado ao Congresso Nacional para aprovação.

Em 6 de fevereiro do mesmo ano foi aprovada a Lei n. 13.979, tendo como meta medidas que viabilizasse o combate ao vírus e, ao mesmo tempo dando autonomia as autoridades de adotar medidas necessárias como isolamento social, quarentena e procedimento médico laboratorial.

Observa-se que a Medida Provisória n. 956 datada de 20 de março de 2020, estabelece a proibição de forma temporária nas rodovias, portos e aeroportos, referente a entrada e saída no país, como também a locomoção interestadual e intermunicipal. 
A medida de isolamento social é introduzida através da portaria n. 356 datada de il de março de 2020 .

Em consonância com a atual situação mundial, a portaria n. 5 determina claramente que o descumprimento das medidas estabelecidas na Lei n. 13.979/20, fica sujeito às penalidades previstas nos artigos 268 e 330 do Código Penal, com data de 17 de março de 2020,

A mesma Lei autoriza que medidas de combate à Covid-ı́ sejam tomadas por autoridades federais, estaduais e municipais.

Conforme acima foi demonstrada algumas normas jurídicas que foram aplicadas por conta da repercussão mundial que a Covid-ıg trouxe à população mundial. $O$ fato que este vírus mudou de forma considerável as normas pelo mundo, fazendo que as autoridades globais buscassem caminhos para que o vírus não se propagasse com tanta velocidade. Deste modo observamos que existem claramente dois lados de uma mesma moeda, sendo o Estado estabelecendo e modificando normas de modo a adequar a população a uma nova realidade e do outro lado a sociedade que deve seguir as diretrizes para ajudar a impedir a propagação do vírus.

\section{COVID-19 NA SOCIEDADE}

O confinamento social imposto pelo governo brasileiro ocasionou a necessiade de que medidas fossem tomadas no campo jurídico, envolvendo dentre outros o direito internacional, o direito do processo penal e o direito penal. Claro que temos a nossa constituição que garante o estado democrático de direito elencando seus princípios, porém tais mudanças impactam diretamente na sociedade e na vida de cada pessoa.

"A tarefa fundamental do Estado Democrático de Direito consiste em superar as desigualdades sociais e regionais e instaurar um regime democrático que realize a justiça social”, conforme José Afonso da Silva,

Dentre outras medidas de combate a pandemia no Brasil, a Lei 13.979/20, estabelece claramente que diversas medidas de combate referente a emrgência de saúde pública de relevância internacional. Estando a Lei regulamentada em portaria n. 356 datada de II de março de 2020, mas precisamente o artido $3 . \stackrel{\circ}{\text { - }}$ referente à medida de isolamento:

Art. 3..$^{\circ}$ A medida de isolamento objetiva a separação de pessoas sintomáticas ou assintomáticas, em investigação clínica e laboratorial, de maneira a evitar a propagação da infecção e transmissão local.

$\S$ I. o A medida de isolamento somente poderá ser determinada por prescrição médica ou por recomendação do agente de vigilância epidemiológica, por um prazo máximo de 14 (catorze) dias, podendo se estender por até igual período, conforme 
resultado laboratorial que comprove o risco de transmissão.

§ 2. ․ A medida de isolamento prescrita por ato médico deverá ser efetuada, preferencialmente, em domicílio, podendo ser feito em hospitais públicos ou privados, conforme recomendação médica, a depender do estado clínico do paciente.

§ 3. Não será indicada medida de isolamento quando o diagnóstico laboratorial for negativo para o SARSCOV-2.

$\S 4^{\underline{0}}$ A determinação da medida de isolamento por prescrição médica deverá ser acompanhada do termo de consentimento livre e esclarecido do paciente, conforme modelo estabelecido no Anexo I.

§ 5.․ A medida de isolamento por recomendação do agente de vigilância epidemiológica ocorrerá no curso da investigação epidemiológica e abrangerá somente os casos de contactantes próximos a pessoas sintomáticas ou portadoras assintomáticas, e deverá ocorrer em domicílio.

§ 6. o Nas unidades da federação em que não houver agente de vigilância epidemiológica, a medida de que trata o \& $5 .^{\circ}$ será adotada pelo Secretário de Saúde da respectiva unidade.

$\S 7 .^{\circ}$ A medida de isolamento por recomendação será feita através de notificação expressa à pessoa contactante, devidamente fundamentada, observado o modelo previsto no Anexo II.

$\mathrm{Na}$ esfera administrativa, o descumprimento das normas acima elencadas acarreta o que dispõe o artigo ı, VII da Lei 6.437/77:

Art. ıo - São infrações sanitárias:

(...)

VII - impedir ou dificultar a aplicação de medidas sanitárias relativas às doenças transmissíveis e ao sacrifício de animais domésticos considerados perigosos pelas autoridades sanitárias:

Pena - advertência, e/ou multa; (Portaria

356 , de II de março de 2020)

As medidas de combate ao novo coronavírus devem ser obedecidas e o seu não cumprimento sujeita a sanções, estando disposto na Portaria Ministerial n. 5 datada de 17 de março de 2020, previstas no artigo $3 .^{\circ}$, $\$ 4 .^{\circ}$ da Lei $13.979 / 20$, como segue:

Art. 3. - Para enfrentamento da emergência de saúde pública de importância internacional de que trata esta Lei, as autoridades poderão adotar, no âmbito das suas competências, entre outras, as seguintes medidas: (Redação dada pela Lei n. ${ }^{\mathrm{O}}$ I4.035, de 2020)

§ $4 .^{\circ}$ As pessoas deverão sujeitar-se ao cumprimento das medidas previstas neste artigo, e o descumprimento delas acarretará responsabilização, nos termos previstos em lei.

Desde sempre na nossa criação somos forjados ao cumprimento das normas, do que é certo ou errado perante a sociedade em nosso quotidiano. Algumas destas normas cumprimos de forma espontânea, naturalmente enquanto outras somos obrigadas e coagidas a realizar, então cabe nos questionar em qual dessas a moral é colocada como principal? Miguel Reale fala:

Podemos dizer que a Moral é o mundo da conduta espontânea, do comportamento que encontra si próprio a razão de existir. $\mathrm{O}$ ato moral 
implica a adesão do espírito ao conteúdo da regra. Só temos, na verdade, Moral autêntica quando o indivíduo, por um movimento espiritual espontâneo realiza o ato enunciado pela norma. Não é coação. (...) Só é possível praticar o bem, no sentidopróprio, quando ele nos atrai por aquilo que vale por si mesmo, e não pela interferência de terceiros". (REALE, 2015, p.44).

O fato que as normas estabelecidas pelo Estado são necessárias para que possamos ter harmonia na sociedade, sejam estas morais, jurídicas ou até de etiqueta. Porém para que estas sejam cumpridas o estado determina sanções para todos que a estas desobedecerem. Claro que toda a sanção tem caráter impositivo, pois vivemos em uma coletividade, onde toda a ação e pensamento devem ser voltados ao coletivo e não ao pensamento unilateral, devendo ser considerado o bem jurídico do outro.

Miguel Reale cita uma frase de importante compreensão acerca das regras sociais e sanções, 'Nós não vivemos apenas voltados para nós mesmos, mas também em função do meio, da sociedade em que agimos". (REALE, 2015, p.73).

Colocando esta frase no mundo atual que vivemos, neste momento pandêmico, o Estado Brasileiro estabeleceu diversos mecanismos portarias, leis, regras e normas com o claro e principal objetivo de que a sociedade seja organizada e possa ocorrer a prevenção almejada, prevenindo assim do Covid-ı. Contudo, observa-se que mesmo utilizando de diversas ferramentas de controle a desobediência não acarreta a consequência a um cidadão, pois a sua indisciplina gera a propagação do vírus e obviamente que diversas pessoas sejam acometidas pela infecção, logo a sua ação ocasionou um prejuízo a sociedade.

Miguel Reale define que o conceito de sanção, in verbis:

A sanção, portanto, é um gênero de que a sanção jurídica é espécie. Existem sanções morais e jurídicas, correspondentes, respectivamente, às regras de natureza moral e jurídica. Há também sanções próprias das normas religiosas, que dizem respeito à crença e à fé, fundadas na esperança ou certeza de uma vida ultraterrena, na qual cada homem receberá a retribuição da sua conduta, a paga ética, ideal, do seu comportamento". (REALE, 2015, p.75).

A sanção estabelecida pelo Estado é uma consequência punitiva pelo descumprimento de uma Lei ou norma jurídica.

\subsection{Covid-19: doenças com potencial de contágio e o Direito Penal}

O aparecimento deste novo vírus em escala global, estabelece a necessidade que diversos atos procedimentais sejam adotados a visar minimizar o dano que pode causar tanto física como 
psicológica junto a uma sociedade. Logo novas normas são fixadas ao arcabouço jurídico, modificando hábitos e preparando a população, buscando que o contágio seja controlado.

Diante de tantas discussões o assunto contágio e a sua contenção tomaram outras proporções gerando a um questionamento que é abrangido no Código Penal Brasileiro, conhecido como periclitação da vida e da saúde.

Existem tipos penais que evidenciam delitos inerentes a doenças contagiosas, mas, quando relativisamos com a Covid-I9, tem pouca relevância, mas outros tipos penais se enquadram na condição pandêmica que estamos a vivenciar no Brasil e mundo e estes apresentaram alterações no período de distanciamento social.

Observe:

\subsection{Contágio por infecção de Moléstia Grave}

Neste caso o dispositivo legal faz menção ao caso de alguém que esteja contaminado e de maneira sagaz e sabedora do que esta fazendo transmitirá a doença a outros indivíduos da sociedade sem, tomar qualquer atitude de prevenção.

Segundo o Código Penal: Art. 131 - Praticar, com o fim de transmitir a outrem moléstia grave de que está contaminado, ato capaz deproduzir o contágio: Pena - reclusão, de um a quatro anos, e multa.

O crime de perigo faz referência ao caso no qual o ato pode ocasionar o contágio, tendo como parte principal a intenção do autor em gerar o contágio e a moléstia grave seja transmitida, porém, no caso de não contração da enfermidade, este responderá pelo delito da mesma forma, estando o fato gerador consumado. Existindo obviamente o perigo de contágio almejado pelo agente, que não conseguiu realizar. $O$ agente, objetiva a transmissão da doença contagiosa, mas este sofrerá a sanção do delito, respondendo do mesmo modo e pena, pois expôs a vítima ao risco de contrair a enfermidade. Porém, não valendo para lesão corporal. O responsável pelo ato infracional é dado como o sujeito ativo, estando a apresentar a moléstia grave e contagiosa, estando no outro lado, qualquerr indivíduo, mesmo que doente como diz o artigo i7 do Código Penal visto que a transmissão de outra doença pode agravar-lhe a perturbação da saúde,

Conforme Cleber Masson é admitido quaisquer meios de execução para a prática delituosa:

O núcleo do tipo é "praticar". Trata-se de crime de forma livre. Admite qualquer meio de execução dotado de capacidade para transmitir a moléstia grave, que pode ser direto, relativo ao contato físico (exemplos: beijo não lascivo, aperto de mão, etc.), ou indireto, referente ao uso de objetos em geral (exemplos: copo d'água, xícara 
de café, etc.).

Moléstia grave é qualquer enfermidade que acarreta séria perturbação da saúde. É irrelevante seja incurável ou não, mas precisa ser transmissível, é dizer, contagiosa. A moléstia venérea, se grave, pode enquadrar-se no crime em análise, desde que o perigo de contágio não ocorra em razão de relação sexual ou de ato libidinoso, pois em tal hipótese incide o delito previsto no art. 130 do Código Penal. Em regra esse crime é comissivo. Nada impede, contudo, seja realizado por meio de uma omissão, quando o agente possuio dever de agir, nos termos do art. 13, § 2.ำ, do Código Penal (crime omissivo impróprio). Exemplo: Comete o delito o pai que observa um estranho espirrar no rosto de seu filho de pouca idade para transmitir-lhe moléstia grave e nada faz para impedir a reiteração deste comportamento ilícito. " (MASSON 2018, p. 159)

Fernando Capez também trata do tema, abordando como necessária a vontade explícita do agente de transmitir moléstia grave:

Não basta a mera consciência" e vontade do agente, molestado, de praticar ato capaz de produzir o contágio, pois o tipo penal exige, além dessa vontade genérica, uma finalidade especial escrita explicitamente no modelo legal, qual seja, "com o fim de transmitir a outrem a moléstia grave”. Ausente essa finalidade, não há o enquadramento legal da conduta ao tipo penal.

Desse modo, no tipo penal em estudo, há o dolo direto de dano acrescido do fim especial de agir: "o fim de transmitir". Não se admite, na espécie, o dolo eventual de dano, em face da sua incompatibilidade com o elemento subjetivo do tipo, que exige expressamente que o agente queira transmitir a moléstia. " (CAPEZ 2019, p. 333)

Os objetos também podem servir de meios de contágios por moléstia grave. Cezar Roberto

Bitencourt, (2015), enfatiza a inviabilidade do agente que usa de objetos contaminados responder pelo delito do artigo I3I do Código Penal, pela falta de elementar típica "de que está contaminado", portanto, configura-se no crime do artigo 132 do Código Penal ou lesão corporal a depender das circunstâncias (Bitencourt, 2015, p.531).

Em sobrevivendo a ação do delito, responderá pelos crimes do artigo 131 e $267 \quad \S^{\circ}{ }^{-}$na modalidade culposa em concurso formal.

Segundo alguns entendimentos este delito tipificado no artigo I3i do Código Penal não há clareza quanto aos crimes que um indivíduo contaminado com o novo coronavírus causa, sendo um crime de moléstia grave, não havendo um posicionamento jurisprudência ou uma doutrina, definindo o assunto proposto, assim podendo ser enquadrado em qualquer tipo de doença, sendo ainda muito precária as informações técnicas sobre o agente etiológico em questão, tornando-se inseguro a condenação do réu no caso deste delito.

Entretanto o entendimento de que o crime do referido artigo não tem uma relevância concreta sobre a Covid-I9, Lucas Montenegro e Eduardo Viana explicam: 


\begin{abstract}
A cláusula "com o fim de", que nesse caso indica um delito de intenção, expressa a necessidade de que o tipo seja realizado com a finalidade especial. Não basta que o sujeito saiba da infecção e queira realizar um ato capaz de contagiar outra pessoa. Transmitir a doença tem de ser a razão pela qual ele realiza a conduta, o seu propósito. Concretamente: alguémque sabe estar infectado e aperta a mão de um conhecido para cumprimentá-lo não tem a intenção de transferir a enfermidade, embora aceite que o aperto de mão possa levar ao contágio. Mesmo que ele tenha certeza do contágio, se agiu com outra intenção, não haverá crime. Claramente, casos dessa natureza serão muito excepcionais, para não mencionar as dificuldades de prova que esse tipo específico de dolo implica. (VIANA; MONTENEGRO, 2020)
\end{abstract}

Em contrapartida, Cezar Roberto Bitencourt no seu livro fala que a conduta tem que ter a finalidade de transmitir a moléstia, ou seja, se a pessoa desconhece que está contaminada não responderá por este crime, todavia, se sobrevier lesão corporal ou morte da vítima e ficar comprovada a existência deculpa, poderá responder pelo crime de lesão corporal seguida culposa ou homicídio culposo, conforme o caso. Entretanto, se a intenção for matar a vítima, poderá configurar homicídio doloso (consumado ou tentado) (Bitencourt, 2015, p.531/535).

Já que não há possibilidade do agente responder pelo perigo de contágio de moléstia grave na forma culposa. Logo as interpretações sobre o assunto diferem quanto ao delito de perigo de contágio de moléstia grave, defendendo a maioria da doutrina que tal delito possui relevância que deve ser evidenciado quando se tratar de Covid-ı.

\title{
2.3 Risco para a Vida e Saúde coletiva
}

No tocante ao tipo penal deste crime, o agente sabendo que está contaminado, acaba negligentemente transmitindo para outras pessoas.

O crime de perigo para a vida e saúde de outrem, elencado no artigo 132 do Código Penal estabelece:

\footnotetext{
Art. 132 - Expor a vida ou a saúde de outrem a perigo direto e iminente: Pena detenção, de três meses a um ano, se o fato não constitui crimemais grave. Parágrafo único. A pena é aumentada de um sexto a um terço se a exposição da vida ou da saúde de outrem a perigo decorre do transporte de pessoas para a prestação de serviços em estabelecimentos de qualquer natureza, em desacordo com as normas legais. (Incluído pela Lei n.ํㅜ 9.777, de 1998)
}

Neste delito, há a desnecessidade do dano, sendo suficiente a exposição do perigo, já que, trata-se de um crime de perigo, que pode ser direto ou eventual. Da mesma forma que o consentimento da vítima é indiferente para aplicação desse crime, em razão da indisponibilidade dos bens jurídicos protegidos. 
Cezar Roberto Bitencourt explica o motivo pelo qual o crime do artigo 132 do Código Penal é de perigo e não de dano, vejamos:

Se o agente pretender, por exemplo, atingir vida ou a saúde de alguém, com sua ação ou omissão estar-se-á diante de uma tentativa de homicídio ou tentativa de lesão corporal, respectivamente. (BITENCOURT, 2015, p.539)

Como se trata de crime de perigo, torna-se possível a concretização da tentativa.

Logo por se tratar de crime de perigo de vida ou a saúde de outrem a ação penal é pública incondicionada, não se exige formalidades ou manifestação da vítima ou do seu representante legal.

\subsection{Epidemia}

O Código Penal no seu artigo 267, descreve:

Vejamos:

Art. 267 - Causar epidemia, mediante a propagação de germes patogênicos:Pena reclusão, de dez a quinze anos. § I $\mathrm{o}$ - Se do fato resulta morte, a pena é aplicada em dobro. § 2.. - No caso de culpa, a pena é de detenção, de um a dois anos, ou, se resulta morte, de dois a quatro anos. (DECRETO- LEI No 2.848 , DE $7 \mathrm{DE}$ DEZEMBRO DE 1940.)

Segundo Cezar Roberto Bitencourt (2015):

A endemia, palavra de origem grega, significa em um povo, abrangendo os processos patológicos e as enfermidades que se manifestam comumente, e ao longo de muito tempo, numa determinada coletividade ou numa zona geográfica. A febre-amarela, por exemplo, é endêmica em determinadas áreas na Amazônia, e a dengue, como dissemos, é endêmica nas regiões tropicais, podendo transformar-se em uma epidemia quando se produz um incremento do número de pessoas infectadas com sintomas da doença, superando os índices de contágio normalmente registrados. Já a pandemia, que, do grego, significa de todo povo, caracteriza-se pela afetação de um grande número de indivíduos ao longo de uma área geográfica extensa, afetando, inclusive, mais de um país. (BITENCOURT, 2015, p.I.139)

Sabemos que o maior bem jurídico tutelado pelo estado é a vida, no caso em questão busca-se a integridade física e a saúde de toda a coletividade que pode ser afetada com a conduta ora estabelecida no tipo penalcorrespondente.

Ressalto que o nosso Código Penal data de 1940, outrora uma época em que não se tratava muito deste assunto, principalmente na diferenciação das definições no tocante a epidemia, endemia e pandemia, assim ocasionando um entendimento único.

Tendo o dolo que é a manifesta vontade livre e de forma conciente de realizar uma 
determinada ação tipificada, causando ou provocando dano, ou seja, o agente da ação tem que ter o objetivo de causar a propagação dos agentes patogênicos, logo quando no fato de desconhecimento da sua contaminação tem o dolo afastado, caracterizando culpa, no caso de negligência, imprudência ou impericia. Porém, se o resultado for a morte da vítima deve haver culpa no precedente e qualificador, necessitando provar haver previsão do óbito.

A consumação do determinado crime se torna consumado quando diversos indivíduos são infectados com a doença, mas existem entendimentos divergentes na doutrina jurídica quanto ao tipo de crime. No entendimento de Guilherme de Souza Nucci (Código Penal Comentado, p. 89I) trata-se de um crime material, cujo resultado integra no próprio tipo penal, enquanto, Juilio Fabbrini Mirabete (Manuel de Direito Penal III, p.Io4) denomina esse crime como de perigo abstrato, sendo desnecessária a comprovação da existência do resultado, Luiz Regis Prado (Curso de Direito penal brasileiro, v.3, p.780) trata-se de um crime de perigo real, onde requer fatos que convença o juiz, da proximidade do possível delito ao bem jurídico e da capacidade de gerar uma lesão ou risco. A maior parte dos doutrinadores caminha na linha do entendimento de que como crime comum, material, vinculadamente ocorrer a propagação de agentes etiológicos patogênicos, comissivo, instantâneo de efeito permanente, entretando, o entendimento de ser instantâneo não é pacífico, devido à consumação da epidemia alonga-se enquanto não forem tomadas medidas para conte-la, unissubjetivo e por fim, plurissubsistente. Admite-se tentativa por se tratar de uma conduta que admite fracionamento, caracterizando a figura qualificado com o evento morte, de forma pretensiosa, aplicando-se a pena em dobro. Contudo, se há culpa no precedente e no resultado qualificador a pena é de detenção de dois a quatro anos, mas, se houver culpa sem resultado, morte teremos uma pena de detenção de um a dois anos, sendo um crime de pequeno potencial ofensivo, com isso, a competência será dos Juizados Especiais Criminais (artigo 6I da Lei 9.099/95). Logo, é de ação penal pública incondicionada.

Desobediência de Medida Sanitária Preventiva. Neste momento de pandemia, tal tipo penal possui grande relevância, tendo muito pontos ainda obscuros a ser esclarecido. $O$ tipo básico do art. 268Código Penal conta com a seguinte redação:

Infringir determinação do poder público, destinada a impedir introdução ou propagação de doença contagiosa: Pena - detenção, de um mês a um ano, e multa. (DECRETO-LEI No 2.848 , DE 7 DE DEZEMBRO DE 1940.)

Neste momento em que o Brasil e mundo se encontra devemos ter muito cuidado com o 
crime ora proposto quando falamos em Covid-19, pois estamos a tratar de saúde pública e atinge um número enorme de vidas, tendo o estado total interesse em promover ações que minimizem os danos, através de normas tendo como orientador o Ministério da saúde para que proceda o controle das ações, prevenir o contágio e impedir a velocidade e a sua proliferação.

Como óvio a tutela é a incolumidade pública, estando o Estado diretamente ligado a todas as ações que possibilitem a redução do contágio, a sua proliferação e velocidade de infecção, como descreve o artigo 196 da Constituição Federal de 1988, vejamos:

Art. 196. A saúde é direito de todos e dever do Estado, garantido mediante políticas sociais e econômicas que visem à redução do risco de doença e deoutros agravos e ao acesso universal e igualitário às ações e serviços para a sua promoção, proteção $e$ recuperação. (Constituição Federal de 1988).

O sujeito ativo, ou seja, aquele que pratica o ato intencionalmente, não apresenta qualidade ou condição especial para este tipo penal, porém se o cometido por funcionário público como, médico, enfermeiro, farmacêutico ou dentista aumenta-se a pena em $\mathrm{I} / 3$, pois haveria infligência ao dever funcional. Caracteriza-se a passividade quando está associada a coletividade e a saúde exposta e sob risco.

O artigo 268 do Código Penal é claramente uma norma em branco, necessita de complementação do poder público, visando que seja impedida a propagação de doença com potencial contagioso e não possa violar os princípios da competência na lei penal material, da reserva legal e constitucional de legalidade.

Sem previsão de culpa, torna-se necessário a evidenciação de qual ação imposta pelo Poder Público que foi descumprida pelo agente intencionalmente.

Quando o agente desconhece tal medida ocorre a impunidade, exceto se provocar uma epidemia, onde o agente responderá pelo crime do artigo 267, 2.ㅇo Código Penal.

Para que haja a consumação do delito é fato a necessidade de que ocorra a desobediência da ordem imposta pelo estado, tendo este o objetivo de evitar a propagação de doença com potencial contagioso, logo um crime de perigo abstrato, porém, deverá demonstrar a idoneidade do agente infrator, já que, para configuração desse delito deve-se produzir um resultado potencialmente ofensivo a preservação do bem jurídico tutelado.

Assim, consuma-se o referido delito com o desrespeito à determinação do poder público municipal, estadual ou federal que vise impedir a introdução ou a propagação do Novo Coronavírus, independentemente da ocorrência do dano efetivo. Por se tratar de crime de perigo abstrato (D’ÁVILA, 2009). 
A figura qualificada se dá com o resultado morte ou lesão corporal,mas apenas na forma culposa, se caracterizado o dolo responde por homicídio doloso ou lesão corporal dolosa. Um exemplo trazido por Cezar Roberto Bitencourt seria no caso de um médico, infringindo intencionalmente uma medida sanitária, provoca um contágio em um paciente, causado a sua morte, a solução, neste caso, seria de homicídio doloso, pois o perigo específico é absorvido pelo resultado, morte (Bitencourt, 20I5, p.I.I47).

Torna-se totalmente possível que o agente responda em concurso formal de crimes, quando a consequência da morte da vítima deriva de um contágio massivo, ou seja, o agente responderá pelo artigo 268 e I2I do Código Penal cominado com o artigo 7o do mesmo código. A ação penal deste delito é pública não condicionada. Ressalta-se que para a configuração do delito do art. 268 são necessárias determinações legais ou regulamentares de cunho obrigatório, não sendo cabíveis meros conselhos ou advertências. A normas tidas em consideração também devem ser específicas para a COVID-ı, e não medidas gerais de higiene. (BAHIA, Saulo José Casali, p.497).

\subsection{O cárcere no contexto da pandemia de COVID-19}

O Departamento Penitenciário Nacional (Depen), o Brasil alcançava um número de 773.15I pessoas que tem privada a sua liberdade, já para o Conselho Nacional de Justiça (CNJ) esse número é maior, cerca de 812 milpessoas, segundo dados do Banco Nacional de Monitoramento de Prisões (BNMP).

Os estabelecimentos prisionais no Brasil apresentam superlotação, má destinação ao esgoto produzido, tratamento de água deficitário e consequente doenças transmissíveis. Diante deste quadro instituições internacionais qualificam o Brasil como o terceiro lugar no mundo que mais exercem a sanção de restringir a liberdade e diante diante desta situação de pandemia torna o quadro preocupante.

A insalubridade pertinente as instituições de cárcere torna viável a proliferação de diversas doenças doenças dentre elas o novocorona vírus. Com base em dados do Infopen, a Rede de Observatório destaca a superlotação penitenciária em alguns estados. Ceará e Pernambuco lideram a superlotação, o primeiro com 173\% e o segundo com 172\% a mais do número de vagas e Rio de Janeiro com $70 \%$ de presos a mais do permitido.

O Estado toma medidas para evitara proliferação da doença, como evitar aglomerações e contato pessoal, higienização das mãos, manutenção da ventilação dos ambientes, atendimento imediato àqueles que apresentarem sintomas e seu devido isolamento social. Mas quando levamos 
nosso olhar para as penitenciárias do Brasil as diligências são difíceis de serem tomadas quando há um grande número de pessoas a mais do que é permitido, sem ventilação, e problemas com o tratamento de esgoto, fornecimento de água e atendimento médico precário, onde não afeta apenas aqueles que cometeram crimes diversos, mas também, aqueles que trabalham nas penitenciárias com o propósito de dar segurança à população.

$\mathrm{O} \mathrm{CNJ}$ estabeleceu recomendação $\mathrm{CNJ}$ 62/2020, que prevê protocolos para luta contra o Covid-ı́ no sistema carcerário, no qual, os Grupos de Monitoramento e Fiscalização do Sistema Carcerário e do Sistema de Execução de Procedimentos Socioeducativos, ostribunais terão de enviar a cada Is dias ao Conselho Nacional de Justiça informações acerca de casos suspeitos e confirmados da Covid-ı, assim como o número de mortes, incluindo os servidores.

Tendo como primordiasl a trazida pela Recomendação 62/2020 que no sentido de diminuir o ingresso de pessoas no sistema prisional e socioeducativo, adotando medidas como a transferência de pessoas presas por falta de pagamento de pensão alimentícia para prisão domiciliar, conforme no artigo 6. da Recomendação 62/2020, e, no caso de adolescentes, a aplicação de medidas socioeducativas em meio aberto e revisão das sentenças que determinam a internação provisória. Destacase, também, a suspensão das audiências de custódia, baseado no artigo $310, \S^{\circ}$ e $\S^{\circ}{ }^{\circ}$ do Código de Processo Penal, vejamos:

Art. 310. Após receber o auto de prisão em flagrante, no prazo máximo de até 24 (vinte e quatro) horas após a realização da prisão, o juiz deverá promover audiência de custódia com a presença do acusado, o seu advogadoconstituído ou membro da Defensória Pública e o membro do Ministério Público, e, nessa audiência, o juiz deverá, fundamentadamente: (Redação dada pela Lei n.o 13.964, de 2019) § $3 .^{\circ}$ A autoridade que deu causa, sem motivação idônea, à não realização da audiência de custódia no prazo estabelecido no caput deste artigo responderá administrativa, civil e penalmente pela omissão. (Incluído pela Lei n. ${ }^{\circ}$ 13.964, de 2019)

$\S 4^{\mathrm{O}}$ Transcorridas 24 (vinte e quatro) horas após o decurso do prazoestabelecido no caput deste artigo, a não realização de audiência de custódia sem motivação idônea ensejará também a ilegalidade da prisão, a ser relaxada pela autoridade competente, sem prejuízo da possibilidade de imediata decretação de prisão preventiva. (Incluído pela Lei no 13.964 , de 2019)

Art. 6o Recomendar aos magistrados com competência cível que considerem a colocação em prisão domiciliar das pessoas presas por dívidaalimentícia, com vistas à redução dos riscos epidemiológicos e em observância ao contexto local de disseminação do vírus. (DECRETO-LEI № 3.689, DE 3 DE OUTUBRO DE 194I.)

Observemos o artigo 2으 da Recomendação 62/2020 que prevê aaplicação de medidas socioeducativas em meio aberto aos adolescentes:

Art. 2.- Recomendar aos magistrados competentes para a fase de conhecimento na apuração de atos infracionais nas Varas da Infância e da Juventude a adoção de 
providências com vistas à redução dos riscos epidemiológicos e em observância ao contexto local de disseminação do vírus, a aplicação preferencial de medidas socioeducativas em meio aberto e a revisão das decisões que determinaram a internação provisória, notadamente em relação a adolescentes:

I -gestantes, lactantes, mães ou responsáveis por criança de até doze anos de idade, ou por pessoa com deficiência, assim como indígenas, adolescentes com deficiência e demais adolescentes que se enquadrem emgrupos de risco;

II - que estejam internados provisoriamente em unidades socioeducativas com ocupação superior à capacidade, considerando os parâmetros dasdecisões proferidas pelo STF no HC no I43.988/ES;

III - que estejam internados em unidades socioeducativas que não disponham de equipe de saúde lotada no estabelecimento, estejam sob ordem de interdição, com medidas cautelares determinadas porórgão do sistema de jurisdição internacional, ou que disponham de instalações que favoreçam a propagação do novo coronavírus; e IV - que estejam internados pela prática de atos infracionais praticados sem violência ou grave ameaça à pessoa. (Recomendação n ${ }^{0} 62$ de 17 de março de 2020).

Contudo, é necessário analisar as prisões em flagrantes, para isso, o CNJ sugere que sejam relaxadas as prisões ilegais, concedida a liberdade provisória, ou de forma excepcional, convertida em prisão preventiva quando se tratar de crimes cometidos com violência ou grande ameaça contra

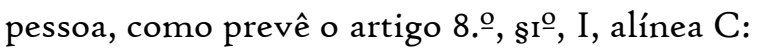

c) excepcionalmente, converter a prisão em flagrante em preventiva, em se tratando de crime cometido com o emprego de violência ou grave ameaça contra a pessoa, desde que presentes, no caso concreto, os requisitos constantes do art. 312 do Código de Processo Penal e que as circunstâncias do fato indiquem a inadequação ou insuficiência das medidas cautelares diversas da prisão, observado o protocolo das autoridades sanitárias. (Recomendação no 62 de 17 de março de 2020).

O exame de corpo de delito deve ser realizado na data da prisão pelos profissionais de saúde no local em que a pessoa presa estiver por registro fotográfico do rosto e corpo inteiro, com o intuito de documentar indícios de tortura ou maus tratos e, se necessário, poderá entrevistar o preso por meios telemáticos.

Nessa entrevista, o magistrado indagará sobre eventuais sintomas do Covid-19, assim como a exposição a fatores tidos como de risco - viagens ao exterior ou contato com pessoas contaminadas se forem apresentados os sintomas, deverá haver a disponibilização a máscara, adoção de procedimentos instituídos pelo Sistema Público de Saúde, e em caso de conversão da prisão em flagrante em preventiva, encaminhamento à rede de saúde para diagnóstico, comunicação e atendimento previamente ao ingresso no estabelecimento prisional, notificando o juízo competente.

Recomendado, aos magistrados, a reavaliação das prisõesprovisórias, priorizando as mulheres gestantes, pessoas presas emestabelecimento com superlotação e prisões preventivas que tenham excedido o prazo de 90 dias ou que estejam relacionadas a crimes praticados sem violência. 
O CNJ aconselha a suspensão do dever de apresentação periódica em juízo as pessoas em liberdade provisória ou suspensão condicional do processo.

Aqueles tribunais e magistrados com competência penal são indicados a priorizar a redesignação de audiências em processos em que o réuesteja solto e através de videoconferência caso seja preso, havendo a necessidade de restrição de visitantes e promover espaços amplos ou aberto, como prevê o artigo 4.ำ e 7.. da Recomendação $62 / 2020$, in verbis

Art. 4..$^{\circ}$ Recomendar aos magistrados com competência para a fase deconhecimento criminal que, com vistas à redução dos riscos epidemiológicos e em observância ao contexto local de disseminação do vírus, considerem as seguintes medidas:

I - a reavaliação das prisões provisórias, nos termos do art. 316 , do Código de Processo Penal, priorizando-se:

a) mulheres gestantes, lactantes, mães ou pessoas responsáveis por criança de até doze anos ou por pessoa com deficiência, assim comoidosos, indígenas, pessoas com deficiência ou que se enquadrem no grupo de risco;

b) pessoas presas em estabelecimentos penais que estejam com ocupação superior à capacidade, que não disponham de equipe de saúde lotada no estabelecimento, que estejam sob ordem de interdição, com medidas cautelares determinadas por órgão do sistema de jurisdição internacional, ou que disponham de instalações que favoreçam a propagação do novo coronavírus;

C) prisões preventivas que tenham excedido o prazo de 90 (noventa) dias ou que estejam relacionadas a crimes praticados sem violência ou grave ameaça à pessoa; II - a suspensão do dever de apresentação periódica ao juízo das pessoas em liberdade provisória ou suspensão condicional do processo, pelo prazo de 90 (noventa) dias; III - a máxima excepcionalidade de novas ordens de prisão preventiva, observado o protocolo dasautoridades sanitárias.

Art. 7.- Recomendar aos Tribunais e magistrados com competência penal que priorizem a redesignação de audiências em processos em que o réu esteja solto e a sua realização por videoconferência nas hipóteses em que a pessoa esteja privada de liberdade, com vistas à redução dos riscos epidemiológicos e em observância ao contexto local de disseminação do vírus. (Recomendação $\mathrm{n}^{0} 62$ de 17 de março de 2020).

Quando tratar de manutenção na realização de audiências, é recomendada a adoção de medidas, que são: a restrição temporária da presençade visitantes do público em geral, tendo que ser em um local aberto ou ampliado, como as salas de júri e auditórios, como a substituição temporária de magistrados e agentes públicos que pertençam ao grupo de risco, a adoção de medidas de

higiene e de prevenção, tais como a disponibilização de água corrente, máscara, álcool gel e demais itens. Dar uma garantia de salubridade e providência de isolamento e, de forma excepcional, uso de algemas, que se necessárias devem ser devidamente higienizadas e por fim, a redução do tempo de permanência nascarceragens dos Fóruns, aplicando-se, no que for cabível, às Varas de Infância de Juventude, como prevê o artigo II. o da Recomendação 62/2020:

Art. II. Quanto às regras de visitação em estabelecimentos prisionais e unidades 
socioeducativas, recomendar aos magistrados que zelem pelaelaboração de plano de contingência pelos gestores competentes, o qual deverá observar preferencialmente os seguintes aspectos:

I - comunicação prévia ao juízo competente acerca de qualquer alteração no regime de visitas e entrega de itens às pessoas privadas de liberdade, particularizando as razões que fundamentaram a decisão, o caráter provisório da medida e o prazo estimado para a sua duração ou reavaliação;

II - notificação prévia ao defensor, familiares e visitantes acerca de qualquer alteração no regime de visitas e entrega de itens às pessoas privadas de liberdade, indicando as razões que fundamentaram a decisão, o caráter provisório da medida e o prazo estimado para a sua duração ou reavaliação;

III - obrigatoriedade de higienização dos espaços de visitação e fornecimento de máscaras e itens de proteção individual aos visitantes, conforme o protocolo sanitário;

IV -proibição da entrada de visitantes que apresentem febre ou sintomas respiratórios associados à Covid-ıg e encaminhamento para o serviço de saúde de referência;

V -adoção prioritária do fracionamento da visitação em diferentes dias e horários, a fim de reduzir o número de pessoas que circulam nos locais e assegurar a manutenção de distância respiratória segura;

VI - previsão de medidas alternativas compensatórias às restrições de visitas, facilitando a utilização de outros meios de comunicação. Parágrafo único. $\mathrm{Na}$ hipótese de restrição de visitas, não poderá ser limitado o fornecimento de alimentação, medicamentos, vestuário, itens de higiene e limpeza trazidos pelos visitantes. (Recomendação no 62 de 17 de março de 2020).

De acordo com o artigo 13. ํ. da Recomendação 62/2020, é aconselhável aos magistrados que priorizem as penas pecuniárias decretadas durante o período de estado de emergência de saúde pública para aquisição dos equipamentos de limpeza, proteção e saúde necessários.

Além disso, os magistrados devem, no âmbito das suas atribuições, informarem à Fundação Nacional do índio (Funai), Secretaria Especial de Saúde Indígena (Sesai), Ministério Público Federal e a comunidade interessada a respeito da adoção de medidas que afetem diretamente pessoas indígenas privadas de liberdade, especialmente quanto ao diagnóstico de Covid-ı́ e a concessão de liberdade provisória ou medidas em meio aberto, fazendo jus ao procedimentodescrito na Resolução $\mathrm{CNJ} \mathrm{n}^{\mathrm{O}} 287 / 2019$.

Portanto, o procedimento a ser adotado para os casos suspeitos ou confirmados de Covid-ig no âmbito dos sistemas prisional e socioeducativo é a separação daquele que apresentar qualquer sintoma do vírus ou aquele que teve contato com um caso suspeito ou confirmado, bem como, o encaminhamento imediato para implementação do protocolo de tratamento previsto pelo Ministério da Saúde com notificação à Secretaria Municipal de Saúde. Além da notificação ao juízo competente para avaliar a substituição da prisão ou medida socioeducativa de meio fechado por medida não privativa de liberdade por conta da ausência de espaço para o devido isolamento. Por fim, deve ser 
assegurado o pleno direito à informação sobre as providências adotadas por suspeita ou confirmação de diagnóstico de Covid-ıg às pessoas privadas de liberdade, bem como aos seus familiares e defensores.

\section{CONCLUSÃO}

Diante de tudo que foi contemplado fica claro que o combate a pandemia deve ser uma ação de todos e cada parte buscando realizar a sua parte corretamente, o estado provendo as condições ideias e a sociedade buscando prestar obediência os decretos, leis e procedimentos ora sugeridos. O novo coronavírus possui enorme potencial de letalidade e ninguém está livre e salvo, caso a sociedade e o Estado deixem de realizar cada um sua função, estaremos diante de uma tragédia muito pior do que vemos hoje em dia. Fica óbvio que a não observância as demandas exigidas irá ocasionar uma deflagração e propagação do vírus em uma escala que não pode ser imaginada e muitas pessoas perecerão, a Covid-ı́ é um vírus que não obedece a padrões e o qual pouco conhecemos, deixar de fazer a sua parte determinará o acometimento de muitas pessoas e da sociedade na totalidade, todo cidadão tem uma regra moral e jurídica a cumprir, como zelar pelo maior bem jurídico que é a vida e caso assim não o faça responderá por um delito específico de acordo com o caso em concreto.

Referente as instituições prisionais no Brasil, estamos certos que são locais de nenhuma ou quase condições de vida, pois apresentam todos os adjetivos para propagação de todas as doenças, inclusive da Covid-ı́, sem higiene, tratamento de esgoto e água, aliados a superlotação, neste ponto cabe ao estado tomar medidas urgentes para modificar este quadro, buscando ações sugeridas pelo Conselho Nacional de Justiça através do da Recomendação 62/2020.

Não se trata somente de respeitar as leis e sim de respeitar a vida, conseguir entender que devemos agir moral e juridicamente acertadamente, buscando manter a vida para a nossa e próximas gerações.

\section{REFERÊNCIAS BIBLIOGRÁFICAS}

BITENCOURT, Cezar Roberto. Código Penal comentado. São Paulo, Saraiva, ed.9, 2015.

CLARO, Amanda Maria. IMPACTOS SOCIOECONÔMICOS DO CORONAVÍRUS E DE OUTRAS DOENÇAS NO MUNDO E NO BRASIL. [s. l.], 17 abr. 2020. Disponível em: https://www.uniara.com.br/noticias/47698/artigo-impactos-socioeconomicos-do coronavirus-e-deoutras-doencas-no-mundo-e-no-brasil/. Acesso em: 2I jul. 2020. 
CAPEZ, Fernando. Curso de direito penal, volume 2, parte especial : arts. I21 a 212. São Paulo: Saraiva Educação, 2019 .

Direitos e deveres fundamentais em tempos de coronavírus / coordenação e organização de Saulo José Casali Bahia e Carlos Eduardo Behrmann Rátis Martins. São Paulo: Editora Iasp, 2020. volume 2. 51op.

D'AVILA, Fabio Roberto. Ofensividade em Direito Penal: escritos sobre a teoria do crime como ofensa a bens jurídicos. Porto Alegre: livraria do Advogado, 2009.

DEPARTAMENTO PENITENCIÁRIO NACIONAL. Ministério da Justiça e SegurançaPública.

\section{Prevenção ao COVID-19 no Sistema Prisional - Informações}

Complementares. P, [s. l.], 9 abr. 2020. Disponível em: https://www.gov.br/depen/pt$\mathrm{br} /$ assuntos/acoes-contra-pandemia/prevencao-ao-covid-I9-no-sistema-prisional- informacoescomplementares.> Acesso em: 26 ago. 2020.

SILVA, José Afonso da. Curso Direito Constitucional Positivo. São Paulo:Malheiros, 1994, p.rio.

Masson, Cleber. Direito penal: parte especial: arts. I2I a 212. Rio de Janeiro:Forense, 2018.

REALE, Miguel. Lições preliminares de direito. São Paulo, ed. 27, Saraiva, 2002.15 ${ }^{\underline{a}}$ triagem, 2015.

VIANA, Eduardo; MONTENEGRO, Lucas. Coronavírus: um diagnóstico jurídico-penal: Algumas reflexões sobre os tipos penais relevantes numa situação de epidemia e pontos legislativos controversos. [s. l.], 23 mar. 2020. Disponível em: https://www.jota.info/opiniao-eanalise/colunas/penal-em-foco/coronavirus-um- diagnostico-juridico-penal-23032020. Acesso em: 28 jul. 2020 . 